Curreli, A.; Wallace, H.; Freeman, C.; Hollingham, M.; Stratford, C.; Johnson, H.; Jones, L. 2013. Eco-hydrological requirements of dune slack vegetation and the implications of climate change

Copyright (C) 2012 Elsevier B.V.

This version available http://nora.nerc.ac.uk/20907/

NERC has developed NORA to enable users to access research outputs wholly or partially funded by NERC. Copyright and other rights for material on this site are retained by the rights owners. Users should read the terms and conditions of use of this material at http://nora.nerc.ac.uk/policies.html\#access

NOTICE: this is the author's version of a work that was accepted for publication in Science of the Total Environment. Changes resulting from the publishing process, such as peer review, editing, corrections, structural formatting, and other quality control mechanisms may not be reflected in this document. Changes may have been made to this work since it was submitted for publication. A definitive version was subsequently published in Science of the Total Environment (2013), 443. 910919. 10.1016/j.scitotenv.2012.11.035

www.elsevier.com/

Contact CEH NORA team at noraceh@ceh.ac.uk

The NERC and CEH trademarks and logos ('the Trademarks') are registered trademarks of NERC in the UK and other countries, and may not be used without the prior written consent of the Trademark owner. 


\title{
Eco-hydrological requirements of dune slack vegetation and the implications of climate change.
}

Curreli A. ${ }^{\mathrm{a}}$, Wallace H. ${ }^{\mathrm{b}}$, Freeman C. ${ }^{\mathrm{a}}$, Hollingham M. ${ }^{\mathrm{c}}$, Stratford C. ${ }^{\mathrm{d}}$, Johnson H. ${ }^{\mathrm{e}}$, Jones L. ${ }^{\mathrm{e}} *$

${ }^{a}$ School of Biological Sciences, Bangor University, Deiniol Road, Bangor, Gwynedd, LL57 2UW, UK. angela.curreli@ hotmail.it, c.freeman@bangor.ac.uk

${ }^{\mathrm{b}}$ Ecological Surveys (Bangor), The School House, Canon Pyon, Herefordshire, HR4 8PF, UK. mikehilary@ecosurvey.demon.co.uk

${ }^{\mathrm{c}}$ Martin Hollingham Hydrological Services, Ty Newydd, Church St, Newborough, Anglesey, LL61 6SD, UK. Martin.hollingham@gmail.com

${ }^{\mathrm{d}}$ Centre for Ecology \& Hydrology, Maclean Building, Wallingford, Oxfordshire, OX10 8BB, UK. CSTR@ceh.ac.uk

${ }^{\mathrm{e}}$ Centre for Ecology \& Hydrology, Environment Centre Wales, Bangor, Gwynedd, LL57 2UW, UK. LJ@ceh.ac.uk

*Corresponding author: Jones L. LJ@ceh.ac.uk, +44 (0)1248 374500, Fax +44 (0)1248 362133.

\begin{abstract}
Dune slacks are a seasonal coastal wetland habitat, whose plant assemblages and soil properties are strongly linked to a fluctuating water table. Climate change is predicted to cause major shifts in sand dune hydrological regimes, yet we know remarkably little about the tolerance of these communities to change, and their precise hydrological requirements are poorly quantified. Dune slack vegetation and soils were sampled within five vegetation types across four west coast UK sites. Relationships between vegetation assemblages, and parameters of soil development (moisture, loss on ignition, $\mathrm{pH}, \mathrm{KCl}$ extractable ions) and groundwater hydrological regime (annual maximum, minimum water levels and range, duration of flooding) were established to define the environmental tolerances of different communities. In multivariate analysis of the vegetation, the dominant gradient was hydrological: dry to wet, followed by a secondary soil development gradient: young calcareous organic-poor soils to acidic/neutral soils with greater organic matter contents. Most measured hydrological and soil variables explained a significant proportion of observed variation in species composition when tested individually, with the exception of soil nitrate and soil calcium concentrations. Maximum water level was the key hydrological variable, and soil moisture and soil $\mathrm{pH}$ were the key soil variables. All hydrological and soil parameters together explained $22.5 \%$ of the total species variation. There were significant differences in hydrological and soil parameters between community types, with only $40 \mathrm{~cm}$ difference in mean annual minimum water levels (averaged over four years) separating the wettest and the driest dune slack communities. Therefore, predicted declines in water level exceeding $100 \mathrm{~cm}$ by 2080 are likely to have a major impact on the vegetation of these priority conservation habitats.
\end{abstract}

Keywords: hydroecology; sand dunes; groundwater; global change; water table. 


\section{Introduction:}

49 Sand dunes are rich in biodiversity due to the heterogeneity of habitat niches, and have both considerable amenity value and a strategic function as coastal defence (e.g. Everard et al. 2010; Louisse and van der Meulen, 1991). Dune slacks are seasonally flooded humid depressions between dune ridges, and are a priority habitat for rare species of conservation importance, including orchids such as Liparis loeselii, Dactylorhiza praetermissa and Dactylorhiza purpurella, lower plants like Petalophyllum ralfsii, a liverwort listed in Annex II of the European Union Habitats Directive, and amphibians like Epidalea calamita which breed in temporary pools (Smith, 2006). Many of these species are restricted to pioneer or successionally young vegetation communities (Davy et al., 2006; Rhind and Jones, 1999; Sival et al., 1998) where competition is low.

Dune slacks form when bare sand is disconnected from seawater influence by the establishment of a new dune front, or inland, where wind erosion scours bare sand down to the water table or to the capillary wetted layer (Ranwell, 1960). Thus their formation and subsequent plant and soil development are intimately connected to the dune groundwater hydrological regimes. Large water table fluctuations are a feature of most slacks, and control slack vegetation development. Variation of water levels occurs both within the year, typically around $70 \mathrm{~cm}$ with a rapid rise in autumn and a gradual decrease from spring to summer

67 (Ranwell, 1959) and between years, depending on precipitation and evapotranspiration 68 balances (Ranwell, 1959).

Winter flooding, intensity of drought and persistence of waterlogging in the rooting zone during the growing season are key environmental factors affecting vegetation, through impacts on germination and productivity (Ernst, 1990; Grootjans et al., 1998). The timing and 
duration of these events can alter inter/intraspecific competition, thus changing community matter accumulation. composition (Bossuyt et al., 2003; Bossuyt et al., 2005). Groundwater fluctuations also control nutrient status: high water levels in slacks reduce the mineralisation of organic matter, maintaining low nitrogen and phosphorous levels (Lammerts and Grootjans, 1997). The chemistry of groundwater is important, and can vary considerably across a site (Jones et al., 2006). In older de-calcified dune slacks, buffering action of carbonate-rich groundwater allows the survival of basiphilous wetland plants (Grootjans et al. 1988, 1991; Sival et al. 1998; Van Dijk and Grootjans, 1993).

Most authors agree that species distribution and community structure across slacks are highly correlated with groundwater levels (Grootjans et al., 1991, 1998; Jones and Etherington 1971; Lammerts et al. 1998, 2001; Noest, 1994; Olff et al. 1993; Ranwell, 1960; Sival et al., 1998; Van der Laan 1979; Willis, 1959b). The differentiation as wet or dry slacks and the hydrological characteristics of different communities are well understood by ecologists (e.g. Rodwell, 2000). Yet, despite this, the precise eco-hydrological requirements of these communities are poorly, if at all, quantified in the UK. In the Netherlands there is a wealth of ecohydrological knowledge on dune slacks (e.g. Witte et al. 2007; von Asmuth et al. 2012), but slacks in the UK differ somewhat from those on the continent. In general they experience higher rainfall, they are often present on narrower dune sites with greater potential for groundwater influence from inland. In the majority of west coast sites, the sand parent material is usually more calcareous, resulting in highly buffered systems with slower decalcification rates, despite the higher rainfall. However, in north UK, slacks can be less well buffered and higher rainfall leads to decalcification of surface soils and rapid organic 
Previous attempts to define eco-hydrological requirements for UK dune slack communities have been based on relatively small numbers of combined vegetation and hydrology records (Ranwell 1959), and conducted at single sites (Jones, 1993; Ranwell, 1959). A further failing is the short duration of hydrological records considered: two years or less, with little understanding of longer term hydrological variability and whether the vegetation is in equilibrium with hydrological conditions (Davy et al., 2010).

104

Dune slack habitats worldwide are under increasing anthropic pressure from water abstraction, afforestation, urbanisation (Grootjans et al. 1998; Martinez et al., 2004; Provoost et al., 2011), nitrogen deposition (Jones et al., 2004; Plassmann et al., 2008; Sival and Strijkstra-Kalk, 1999) and from grass and scrub encroachment or exotic species invasion (Martinez et al., 2004). In addition, changes in evapotranspiration due to vegetation change or management will affect the water balance (Davy et al. 2010; Ford et al. 2012). An emerging

111 threat is climate change, which may shift the biogeographical range of dune slack species, but

112 which also alters the dune environment. Changes in precipitation and temperature affect

113 groundwater levels directly by altering the delicate balance between rainfall and evapotranspiration, which controls recharge. Sea-level rise or shoreline erosion act indirectly on groundwater levels by altering water table gradients (Clarke and Sanitwong Na Ayutthaya, 2010; Saye and Pye, 2007). Modelling of groundwater trends for dune slacks in a sand dune

117 system in north west England based on long term records, predicted a substantial lowering of

118 water levels of 1 to 3 metres over the next 90 years (Clarke and Sanitwong Na Ayutthaya,

119 2010). Physiological adaptations typical of plants growing on humid calcareous substrates

120 can make them less resilient to rapid habitat changes (Bakker et al., 2007; Grootjans et al.,

1212004 ; Schat, 1984) and the rapidity of community shifts in response to variations of

122 groundwater regime is difficult to estimate (Noest, 1994; Van der Laan, 1979). The predicted 
123 changes in water levels are so large that major changes in slack vegetation are probable, but

124 the outcomes will remain uncertain until we better understand the hydrological requirements

125 of these vegetation communities.

126

127 The aim of this investigation was therefore to improve our understanding of the relationships

128 between dune slack vegetation communities and the underlying hydrological and

129 biogeochemical controls, across a range of west coast UK sites, through the following steps:

130

131 1. Creating a network of co-located vegetation and hydrological monitoring locations,

132 maximising the use of previously unconnected long-term vegetation or hydrological data

133 records.

134 2. Using multivariate analysis to determine the principle environmental parameters governing

135 species assemblages in sampled dune slack communities.

136 3. Using hydrological data from a reasonably climatically stable four year period, to

137 characterise the hydrological and environmental requirements of each community type.

138 4. Interpreting those requirements in the light of predicted climate change impacts on dune

139 groundwater regimes.

140

141 Using this information, the following specific questions were postulated. Can vegetation

142 communities be distinguished according to hydrological regime? Are projected changes in

143 groundwater regime likely to have serious consequences for current dune slack assemblages?

145 2. Methods:

$146 \quad 2.1$ Study sites 
147 Data were collected from four dune systems on the west coast of the UK (Table 1).

148 Newborough Warren, a dune system located on the SW corner of the Isle of Anglesey in

149 North Wales, UK, which contains all five of the UK slack communities. The sand dune area

150 has developed between two estuaries; the western part of the dunes has been forested with

151 Pinus nigra ssp. 1aricio commencing in 1948. Aberffraw, close to Newborough ( $6 \mathrm{~km}$ north

152 west), is a smaller system about $1 \mathrm{~km}$ wide and extending $3 \mathrm{~km}$ inland, enclosed within a

153 valley. Ainsdale Sand Dunes National Nature Reserve in the Sefton coast (Merseyside, UK),

154 the largest area of open dune landscape in England, where part of the dunes are also forested

155 (Pinus nigra ssp. laricio), and Whiteford Burrows National Nature Reserve, a spit dune

156 system on the south side of the Loughor estuary, Gower Peninsula, South Wales. Here the

157 dunes are bounded by saltmarsh on the east side and also partially afforested in the southeast.

158 All sites are grazed by rabbits and, within fenced areas, are grazed by domestic livestock

159 (Welsh mountain ponies, cattle and sheep). Climate in these locations can be defined as

160 oceanic, with mild winters and cool summers. Long-term annual rainfall (1971-2001) at the

161 sites varies from 828 to $1107 \mathrm{~mm}$ (Table 1); evapotranspiration in these dune slacks can vary

162 between 360 and $550 \mathrm{~mm} /$ year depending on slack wetness and grazing pressure (Stratford et 163 al., 2007).

164

165 [Table 1 about here]

166

\subsection{Vegetation communities}

168 In the UK, five dune slack vegetation communities have been described (Rodwell, 2000) with

169 a number of sub communities. These vary from younger base-rich slacks through to older,

170 decalcified communities, and range from wet to dry types. The main communities and

171 subcommunities described in this study are summarised in Table 2, together with a dry dune 
172 grassland community (SD8), which forms the common dry end-point of the driest slack community SD16.

\subsection{Hydrological data.}

176 Even though water table levels and vegetation are monitored in several dune systems in the

177 UK, their sampling locations rarely coincide. At Newborough there was an existing network

178 of piezometers in the dunes, with the oldest hydrological records dating to 1985 . The majority

179 of wells were located in a single community type, SD14, therefore new piezometers were

180 installed in early 2010 in other vegetation types, and adjacent to permanent vegetation

181 quadrats established in 1987 (Plassmann et al. 2010). Additional transects of wells were

182 installed across natural vegetation gradients in three slacks. New piezometers were also

183 installed at Aberffraw, while existing piezometers were used at Ainsdale and Whiteford

184 Burrows (Table 1), giving a total of 58 useable piezometers across all sites.

186 Monthly manual measurements of groundwater levels were made in all 58 piezometers from

187 early 2010 for a period of 18 months. Older data at monthly resolution were available since 2006 for 16 piezometers at Newborough. Automatic logging water level recorders (DIVER®,

189 Schlumberger, The Netherlands) were located in some of these older piezometers, and

190 additional loggers installed in a selection of new piezometers, providing higher temporal

191 resolution and independent verification of water levels at these locations. However, for

192 statistical analysis, monthly resolution manual data were used from all piezometers to

193 maximise spatial coverage across the sites. A hydrological year commencing on $1^{\text {st }} \mathrm{June}$,

194 during the summer water table decline was used as the basis for summary variables, in order

195 to reliably record minimum and maximum water table heights in the same year, since timing

196 of the rapid autumn re-wetting can vary considerably from year to year. The following 
197 hydrological variables were extracted from monthly records for 2010 and for longer time

198 series where available: minimum water level, maximum water level, $10^{\text {th }}$ and $90^{\text {th }}$ percentiles

199 (in case of truncation of records), annual range (maximum minus minimum water level), an

200 estimated duration of flooding (assuming that where the water table was at or above the

201 ground surface flooding occurred for four weeks), annual median (only calculated from 2006

202 to 2009), seasonal (spring, summer, autumn, winter) averages and averages for spring months 203 (March, April, May and June).

204

205 [Table 2 about here]

\subsection{Vegetation survey}

208 Vegetation was surveyed in $1 \mathrm{~m} \times 1 \mathrm{~m}$ quadrats around existing and newly established

209 piezometers. Quadrats were arranged as a cross around the piezometers, with an additional

210 quadrat placed in the most homogeneous part of the stand. Species occurrence was recorded

211 as cover values (using visual estimates of percentage cover); nomenclature follows Clapham

212 (1987) for vascular plants, since it is compatible with NVC community descriptions, and Hill

213 (1991-94) for bryophytes. Physiognomical parameters, such as vegetation height, bare

214 ground and litter cover, evidence of grazing, slope and aspect, were recorded for each

215 quadrat. The location of the centre of each quadrat was recorded using a Leica 1200

216 RTKGPS.

\subsection{Topographical resolution}

219 Elevation of the ground surface at each piezometer and each quadrat was also measured using

220 the Leica 1200 RTKGPS, with a vertical accuracy of $\pm 1 \mathrm{~cm}$. This provided elevation relative

221 to the water table measured at nearby piezometers, used to derive adjusted hydrological 
summary data for each quadrat. Field-testing showed that water table height varied by less than $5 \mathrm{~cm}$ within $7 \mathrm{~m}$ of a piezometer and this was deemed acceptable variation without adjustment. At greater distances groundwater depth was measured using an auger, or quadrats were excluded from analysis.

\subsection{Soil survey and laboratory measurements}

At each quadrat a soil sample was collected, $5 \mathrm{~cm}$ in diameter to a depth of $15 \mathrm{~cm}$. Samples were stored in the dark at $5^{\circ} \mathrm{C}$ until processed. After measuring depth of the organic horizon, large roots were removed and the samples thoroughly mixed. Ten grams of mixed fresh sample were weighed and dried overnight at $105^{\circ} \mathrm{C}$ to measure moisture content. Loss On Ignition was calculated by re-weighing the samples after 16 hours at $375^{\circ} \mathrm{C}$. pH was measured after 30 min equilibration of 10 grams dry soil stirred in $25 \mathrm{ml}$ deionised water, with $\mathrm{pH}$ electrode calibrated with standard solutions. Water-extractable soil nutrients were sampled using a solution prepared with 5 grams of dry soil in $45 \mathrm{ml}$ of ultra high purity water $(1: 10 \mathrm{wt} / \mathrm{vol})$, shaken for $24 \mathrm{hrs}$ at $70 \mathrm{rpm}$ in the dark followed by centrifugation at $5000 \mathrm{rpm}$ for 10 minutes, and finally filtered through $0.45 \mu \mathrm{m}$ cellulose nitrate filters. Extracts were analysed using a Metrohm ion chromatograph. Reference soils and duplicates were used for quality assurance.

\subsection{Statistical analysis}

Groups of quadrats with similar vegetation were identified using cluster analysis in TWINSPAN (Two-Way INdicator SPecies ANalysis, Hill, 1979b). The UK National Vegetation Classification (NVC) unit (Rodwell, 2000) for each of these clusters was assigned using MATCH software (Malloch, 1998). In order to determine whether quadrats represented 'core' good quality vegetation or 'transitional' vegetation, they were also assigned individually to an NVC unit using MATCH. If the quadrat assignation matched that of its 
parent cluster, it was classed as 'core', if it did not match, or was intermediate between two or more communities it was classed as 'transitional'. Mean unweighted Ellenberg scores for light (L), moisture $(\mathrm{F})$, reaction/pH (R) and nutrients $(\mathrm{N})$ (Ellenberg et al., 1991) were calculated for each quadrat using UK Ellenberg indicator values for vascular plants and bryophytes (Hill et al., 1999).

The relationship between the vegetation and environmental variables was explored through indirect gradient methods using Principal Component Analysis (PCA) after testing the length of the first gradient for linearity of response gradients (CANOCO 4.0, ter Braak and Smilauer, 1998). The main hydrological and soil parameters were then used in a direct gradient method using Canonical Correspondence Analysis (CCA) for a subset of 189 quadrats, excluding those too far from the piezometers or with missing data. Significance of environmental variables in the CCA was assessed using Monte Carlo methods within CANOCO.

Since the majority of piezometers had only one year of hydrological records, it was explored whether piezometers with longer time series could be used to extrapolate longer-term hydrological trends. Average annual values for the hydrological parameters minimum water level, maximum water level and range were calculated for a four year sequence (2006 2009) for twelve piezometers located in the main dune slack community types. Relationships between the longer-term data and the data for 2010 were established using linear regression,

269 and were all significant (Maximum water level, $\mathrm{R}^{2}=89.2 \%, \mathrm{p}<0.001$; Minimun water level, $270 \quad \mathrm{R}^{2}=96.6 \%, \mathrm{p}<0.001 ;$ Range, $\left.\mathrm{R}^{2}=37.4 \%, \mathrm{p}=0.009\right)$. These equations were used to calculate

271 four-year averages for the wider set of piezometers and associated quadrats. Frequency

272 distributions of water levels for each community were calculated from mean and standard 
273 deviation of annual median water levels calculated for all quadrats within each vegetation

274 community type, assuming a normal distribution.

275

276 Differences between vegetation clusters (or NVC units) for the main hydrological (minimum

277 and maximum water levels, and annual range) and other environmental variables (soil $\mathrm{pH}$,

278 soil moisture and percentage Loss On Ignition, percentage bare ground and litter) were assessed by Analysis Of Variance, performed on the 2010 variables using Minitab v. 16.

Summary hydrological data for each community were calculated from the four-year averages predicted from regression analysis. Data transformation was necessary for almost all soil elements, since data were not normally distributed (Kolmogorov-Smirnov test). Chloride, phosphate, sulphate, nitrate, potassium and sodium were natural log transformed, ammonium was square root transformed. Nitrite was excluded from the analysis due to excessive missing values.

\section{Results:}

289 The initial cluster analysis allocated the 245 quadrats to seven dune slack and grassland units of the UK National Vegetation Classification (Rodwell, 2000). To illustrate differences in the hydrological regimes underlying the main communities, Figure 1 shows typical hydrographs over four years from piezometers located in each of the main community types at

293 Newborough Warren. The Potentilla anserina-Carex nigra (SD17) and Salix repens-

294 Calliergon cuspidatum (SD15) communities experienced higher winter water tables and more frequent surface flooding of 10/20 cm compared to the other units. The Salix repens-

296 Campylium stellatum community (SD14, only Bryum pseudotriquetrum-Aneura pinguis

297 SD14c subcommunity shown) showed less annual fluctuation with lower winter but higher 298 summer water table levels. The driest slack community $\underline{\text { Salix repens-Holcus lanatus (SD16) }}$ 
299 had generally lower water tables throughout the year. The groundwater levels underlying dry 300 dune grassland Festuca rubra-Galium verum (SD8) were considerably lower throughout and 301 are shown for comparison.

$303 \quad$ [Figure 1 about here]

The PCA shows the pattern of variation in the quadrats, coded according to vegetation interpretation. The primary axis of variation corresponds to a wetness gradient: Ellenberg F, all the hydrological variables and to a lesser degree soil moisture, were positively correlated with axis 1 scores. The second axis corresponds to soil development, with Ellenberg N, $\%$ LOI and $\mathrm{NH}_{4}{ }^{+}$positively correlated whilst Ellenberg $\mathrm{L}$ and $\mathrm{R}$ and soil $\mathrm{pH}$ were negatively correlated with axis 2 scores. The vegetation communities are arranged along these gradients as follows. The wettest units are SD15b and SD14b, the former extending to older (higher organic matter) and wetter soil conditions, the latter having lower organic matter concentration indicative of younger sites. Quadrats clustering as SD14c have high scores for Ellenberg $\mathrm{L}$ and $\mathrm{R}$ reflecting a species composition characteristic of an open, early successional habitat with abundant heliophilous and basiphilous species growing on young

317 calcareous soils with a thinly developed organic layer. The dry slack community SD16 is

318 concentrated at the right hand side of the diagram indicative of low soil moisture whilst variability along the second axis indicates that it can develop on substrates of varying ages. The dry dune grassland SD8 quadrats are next to those of SD16, associated with older and usually drier soils, although the two communities clearly have overlapping hydrological

322 tolerances on this part of the hydrological gradient. SD14d occupies a position intermediate

323 between the wet SD15b and dry SD16. SD17 is not as well defined as the other communities; 
with only seven quadrats, however, it appears to occupy damper and more mature systems associated with SD14d and SD15b.

327 [Figure 2 about here]

328 [Figure 3 about here]

The CCA (Figure 3) shows the influence of the measured environmental variables (Figure 3a) on the position of all vegetation quadrats (Figure 3b) and of groups consisting only of core vegetation (Figure 3c). The dominant axis relates to hydrology and the second axis to soil development, as in the unconstrained gradient analysis (Figure 2). Communities occupy broadly the same niches as seen in PCA, with some distinctions. The SD8 dry dune grassland and the wet slack SD16 are more clearly separated along the wetness gradient, and communities are more clearly distinguished along the soil development (secondary) axis. However, a key component of Figures $3 b$ and $3 c$ is the very high degree of overlap of the communities along the hydrological gradient represented by Axis 1 .

Significance testing using Monte Carlo permutation showed that the model with all variables was highly significant $(\mathrm{p}<0.001)$. The first four axes explained $61.6 \%$ of the speciesenvironment relationships, but explained a smaller proportion of the total species variance (first four axes 22.5\%). Most variables tested singly were highly significant (Table 3), with annual maximum water level $(6.3 \%)$ and soil moisture $(6.3 . \%)$ explaining the greatest proportion of the total species variance. Only soil available nitrate and calcium were not significant explanatory variables. However, there was a high degree of correlation amongst the hydrological variables and all hydrological variables together explained only $8.9 \%$.

348 Hydrological and soil variables were largely orthogonal, with annual maximum water level,

349 soil moisture and soil $\mathrm{pH}$ explaining $12.9 \%$ of species variance. An extended model 
combining key hydrological (maximum water level), soil (\%moisture, soil $\mathrm{pH}$ ) and soil chemistry parameters $\left(\mathrm{NH}_{4}{ }^{+}, \mathrm{PO}_{4}{ }^{-}\right)$increased the cumulative species variance to $14.6 \%$. Ellenberg indicator values were separately tested as explanatory variables. Ellenberg F explained $10 \%$, Ellenberg $\mathrm{N}$ an additional $7 \%$, and a further $3 \%$ for Ellenberg $\mathrm{R}$; when Ellenberg $\mathrm{L}$ was included in a combined model, together they explained $21.2 \%$ of the variance, similar to the proportion explained by the measured environmental variables.

Water extractable nutrients, presented as average ion concentration in six vegetation communities (combined data from core and transitional vegetation quadrats), showed significant differences between communities (Figure 4): calcium $p=0.05$, potassium $p=0.01$, all other ions $\mathrm{p}<0.001$. Sulphate and phosphate had higher concentrations in SD17 as did nitrate. The other ions presented higher values in SD15b, except calcium, which was more concentrated in SD14 subcommunities. The SD14 subcommunities all had lower concentrations of nitrate, magnesium and potassium than the other communities.

[Figure 4 about here]

[Table 4 about here]

Hydrological parameters, the principal soil parameters and vegetation physiognomy were summarised for the main vegetation communities (Table 4). Minimum and maximum water

370 levels differ significantly between the wetter slack communities (SD15b, SD14b), and the drier communities (SD16, SD14d). Winter water levels of the two wettest units (SD15b and SD14b) differ by around $20 \mathrm{~cm}$ from the slightly drier SD14c and SD14d whilst their summer

373 minimum is at least $10 \mathrm{~cm}$ higher. The dry slack community (SD16) has mean winter and 374 summer levels around 20-25 cm lower than the other slack types. The younger SD14c 
375 subcommunity appears to be intermediate in character regarding water levels, but its annual range $(49 \mathrm{~cm})$ is much lower than the others $(\sim 70 \mathrm{~cm})$. Winter water tables in the dry dune grasslands (SD8) are a further $25 \mathrm{~cm}$ lower on average, although the wettest examples in this study have a winter maximum which overlaps much of the hydrological range of the dry slack community SD16 (Figure 5). \%LOI and pH reflect soil age, with the youngest (SD14c) and older/wetter (SD15) communities differentiated, with the rest intermediate. The older, slightly decalcified, SD17 community, although poorly represented in this study, was not significantly different from SD15 in terms of hydrological and soil parameters, but diverged in bare ground and litter, with $>25 \%$ plant litter compared with $<4 \%$ in the other communities. Figure 5 shows the 67 and 90 percentile ranges for maximum winter water levels and minimum summer water levels for quadrats with core vegetation assemblages only. This shows clearly that the majority of core quadrats in the three main slack assemblages in this study have hydrologically distinct summer and winter water levels.

[Figure 5 about here]

\section{Discussion:}

392 This study has shown that dune slack vegetation assemblages are associated with distinct hydrological regimes, and with differing soil physical and chemical properties, in broad agreement with studies in the Netherlands (e.g. Lammerts et al. 2001). The cluster analysis and PCA axis scores demonstrated a clear separation of vegetation communities based on their species composition with Ellenberg F scores suggesting axis 1 was strongly linked to soil moisture. The majority of environmental variables tested through direct gradient methods (CCA) were significant in explaining species variation. However, although the proportion explained by the species-environment relationships is similar to published studies, e.g. $58 \%$ 
400 for the first two axes in Lammerts et al. (2001), surprisingly little of the overall species

401 variation was explained by the measured environmental parameters. There are a number of

402 potential reasons for this. Firstly, vegetation assemblages are the result of many factors, not

403 just hydrological regime and soil development (Bakker et al., 2006). Inter-specific

404 competition, migration rates and chance colonisation (Bossuyt et al., 2003; Bossuyt et al.,

405 2005) introduce a high degree of heterogeneity to slack vegetation, even to adjoining slacks

406 with similar hydrological regimes on the same site. A similar effect of site overriding

407 hydrological parameters has been shown on floodplain meadows (Kalusova et al., 2009).

408 Other factors such as secondary disturbance, and seed bank longevity also influence

409 composition (Studer-Ehrensberger et al., 1993) and increase heterogeneity. Lastly, grazing

410 pressure varies within and between sites and this may be a factor. However, Plassmann et al.

411 (2010) showed that introduction of grazing had no major effect on slack vegetation at

412 Newborough, with grazing effects secondary to both moisture and soil parameters. In these

413 relatively young (20 - 150 years) well-buffered slacks prior to decalcification, although

414 organic matter accumulates rapidly with age (Jones et al., 2008), slack age is a poor

415 determinant of community type (Jones et al., 2010), nonetheless, it may be an important

416 factor influencing vegetation composition. In contrast to some Dutch systems, salt spray,

417 seawater influence and decalcification (Lammerts and Grootjans, 1998) are not dominant

418 influences here; soil $\mathrm{pH}$ drops to a mean of 6.3 in the older SD17 community. Lastly, this

419 study covered a narrower environmental gradient compared with e.g. Lammerts et al. (2001)

420 who also included primary slacks and those with periodic saline influence, and included

421 samples from the transitional areas between communities rather than focusing on

422 homogenous stands of vegetation (e.g. Rodwell et al. 2000). 
424 A potential issue for interpretation with respect to hydrological regimes is the temporal resolution of the hydrological data. Water level data available at monthly resolution in this study did not allow calculation of sum exceedance values, (i.e. the duration of time the water table is above or below thresholds for drought stress or water logging stress and the cumulative summation of that exceedence) which have been used to interpret plant species hydrological niches in other wetland ecosystems (Gowing et al., 1997). The water-holding capacity and soil permeability alter with organic matter content. As a result, the same water table depth below ground surface may differentially affect communities with different organic profiles and different mineralogy. It is also possible that there is a disconnect between water tables and plant responses in winter and summer, with groundwater levels in summer being less important than rainfall events which may re-wet surface layers and the rooting zone but do not contribute to recharge and therefore changes in water table. Nonetheless, despite these constraints, this study has for the first time identified the average hydrological regimes of a suite of Atlantic wet slack vegetation communities.

439 Relationships are based on hydrological data over a four-year period. This is an improvement on previous ecohydrological studies in the UK based on one or, at the most, two years hydrological data (Jones 1993; Ranwell, 1959), and is consistent with other studies. In Dutch

442 dune slacks Noest (1994) found that 5-yearly means of a range of hydrological parameters 443 provided better explanatory power on species' distribution than the same parameters 444 measured for the year of vegetation recording, or the previous year. In UK wet meadows, the best explanatory power for changes in vegetation is found for hydrological variables over the 446 preceding three to seven year period: Sum Exceedence for waterlogging stress over a 3-year 447 period proved effective for predicting shifts between vegetation communities (Gowing et al., 448 2005) whilst 5-7 year values for aeration and drought stress provide good explanatory power 
449 for stable community distributions (Gowing et al., 2002). In this study we make the

450 assumption that the vegetation communities were in equilibrium with those hydrological

451 conditions, but further work is required to establish variability in dune slack species

452 assemblages between years and in response to changing hydrological regimes.

453

454 Dune groundwater levels are closely tied to climatic patterns and water levels vary 455 considerably from one year to the next. The few long-running records available for the UK spanning several decades show large changes in average water tables, often over decadal scales (Davy et al., 2010; Robins and Jones, 2012). The net recharge to groundwater is strongly dependent on a fine balance between rainfall and evapotranspiration, and is as dependent on the timing of rainfall during the year as it is on total annual rainfall (Clarke and Sanitwong Na Ayutthaya, 2010). This makes dune slacks very sensitive to climatic changes. Studies on the impact of climate change on recharge to aquifers in the eastern UK suggest increasing recharge and water levels over the next few decades but becoming drier thereafter

463 (Younger et al., 2002; Yusoff et al., 2002), while in Ireland, an overall decrease in effective run-off is predicted (Charlton, 2001). Clarke and Sanitwong Na Ayutthaya (2010) used the Darcian groundwater flow equation to model the movement of water through the dunes, which was then used to predict the effects of climate change. Their results suggested a drastic, long-term decline in water levels of more than $100 \mathrm{~cm}$ was highly likely at a west coast UK site. They also showed that climate change impacts on water tables were greater than impacts of afforestation or coastal change. Climate change impacts were a factor of two greater than the effects of sea level rise or afforestation, and an order of magnitude greater than the effects of rapid coastal erosion or accretion. 
473 Although studies in the Netherlands have developed models to predict responses of Dutch 474 dune species to groundwater change (von Asmuth et al. 2012; Witte et al. 2007; Geelen et al. 475 2004), no studies to date have quantified how changing water levels may affect dune 476 vegetation communities in the UK. Findings from this study allow, for the first time, a 477 projection of likely changes in vegetation communities under projected water level decline.

478 Figure 6 shows frequency distributions of median water level for the main slack and dry dune 479 grassland communities in this study plotted against water level projections to the 2080s for 480 what is currently a wet slack type at Ainsdale (after Clarke and Sanitwong Na Ayutthaya, 481 2010). This suggests that towards the end of the 2030s conditions are no longer favourable 482 for wet slacks and only dry slack community can persist. More worryingly, by the end of the 4832050 s it is likely that even dry slack communities will be replaced by dry dune grassland. 484 Although in reality these communities are unlikely to replace each other sequentially (e.g. see 485 Edmondson 1993 for a review of UK dune slack succession), it illustrates the severe shift in 486 hydrological regimes that may occur and shows the implications for vegetation assemblages.

487 These effects only take account of changes in water level. However changes in groundwater 488 chemistry and the interaction with surface soil layers will also occur. Surface soil 489 acidification, which is detrimental for the growth of basiphilous slack species, is a consequence of lowering water levels, due to a reduction in the seasonal replenishment of buffering capacity from base-rich groundwater (Sival and Grootjans, 1996). The diminution 492 of winter flooding is likely to have direct impact on soil chemistry too, changing nutrient 493 accumulation rates (Grootjans et al., 1991), redox processes (Sival and Grootjans, 1996), 494 microbial cycles (Grootjans et al., 1996) and will consequently affect species interactions.

496 [Figure 6 about here] 
498 The effects of climate change may be exacerbated by drainage or groundwater abstraction,

499 and any form of water abstraction should be discouraged (Bakker et al., 2006; Davy et al.,

500 2010; Grootjans et al., 1996; Van Dijk and Grootjans, 1993). In contrast, management

501 techniques which encourage natural sand mobility may guarantee natural renovation of young

502 successional stages, allowing the formation of new blowouts or creation of new secondary

503 dune slack habitat through natural dune dynamics (Davy et al. 2010; Stratford et al., 2007).

504 Other management methods used to improve mobilisation in sand dunes systems (such as sod

505 cutting, removal of invasive scrubs, etc.) may be useful to alleviate detrimental effects of

506 climate change in the absence of natural mobility (Kooijman, 2004).

507

\section{5.Conclusions:}

509 Atlantic dune slack assemblages can be characterised by their hydrological regime and soil

510 parameters. However, there remains unexplained heterogeneity in the vegetation and the

511 measured hydrological and soil parameters explain only $22.5 \%$ of observed variation.

512 Assemblages separate broadly into wet slack, intermediate and dry slack types, with average

513 winter water levels differing by around $20 \mathrm{~cm}$ between categories. Given the magnitude of

514 these differences between community types, projected changes in water levels of over $100 \mathrm{~cm}$

515 due to climate change over the next few decades are a cause for concern. Hydrological

516 regimes may shift completely from those currently associated with wet slacks to regimes

517 currently found under dry dune grassland over a period of 50 years, and management options

518 for responding to these changes should be explored urgently.

519

520 6. Acknowledgements:

521 This project has been made possible by the EU's Convergence European Social Fund through

522 the Welsh Assembly Government and co-funded by the Natural Environment Research 
523 Council. We thank Countryside Council for Wales and Natural England who granted access

524 to the sites, and all technicians in Wolfson Carbon Capture Lab and Centre for Ecology and

525 Hydrology Labs, for support with soil analysis. We also thank Jim Bennell for loan of the

526 RTKGPS.

527

528

7. References:

529

Bakker C, Van Bodegom PM, Nelissen HJM, Ernst WHO, Aerts R. Plant responses to rising water tables and nutrient management in calcareous dune slacks. Plant Ecol 2006;185: $19-28$

Bakker C, van Bodegom PM, Nelissen HJM, Aerts R, Ernst WHO. Preference of wet dune species for waterlogged conditions can be explained by adaptations and specific recruitment requirements. Aquatic Botany 2007; 86: 37-45.

Bossuyt B, Honnay O, Hermy M. An island biogeographical view of the successional pathway in wet dune slacks. J Veg Sci 2003; 14: 781-8.

Bossuyt B, Honnay O, Hermy M. Evidence for community assembly constraints during succession in dune slack plant communities. Plant Ecol 2005; 178: 201-9.

Charlton R, Moore S, Sweeney J, Fealy R. Climate change and water resources in Ireland: initial investigations using downscaled GCMS and hydrological modelling techniques. Cuadernos Invest Geog 2001; 27: 125-35.

542 Clapham AR, Tutin TG, Moore DM. Flora of the British Isles. $3^{\text {rd }}$ ed. Cambridge; 1987.

543 Clarke, D. \& Sanitwong Na Ayutthaya, S. Predicted effects of climate change, vegetation and tree cover on dune slack habitats at Ainsdale on the Sefton Coast, UK. J Coast Cons 2010; 14: 115-25 
546 Davy AJ, Grootjans AP, Hiscock K, Petersen J. Development of eco-hydrological guidelines for dune habitats - Phase 1. 2006 English Nature Research Reports, No 696, Peterborough, UK.

Davy AJ, Hiscock KM, Jones MLM, Low R, Robins NS, Stratford C. Ecohydrological guidelines for wet dune habitats, phase 2. Protecting the plant communities and rare species of dune wetland systems. 2010 Environment Agency, Bristol, UK.

Edmondson SE, Gateley PS, Rooney PJ, Sturgess P. Plant communities and succession. In: Atkinson D, Houston J (eds) The sand dunes of the Sefton coast. National Museums and Galleries on Merseyside, 1993. Liverpool, pp 65-84.

Ellenberg H, Weber HE, Düll R, Wirth V, Werner W, Paulissen D. Zeigerverte von Pflanzen in Mitteleuropa. Scripta Geobotanica. Germany: Göttingen, 1991.

Ernst WHO. Ecophysiology of plants in waterlogged and flooded environments. Aquat. Bot.1990; 38: 73-90.

Everard M, Jones L, Watts B. Have we neglected the societal importance of sand dunes? -

Ford H, Garbutt A, Jones DL, Jones L. Impacts of grazing abandonment on ecosystem service provision: Coastal grassland as a model system. Agriculture, Ecosystems and Environment 2012; 162: 108-115.

Geelen L, Haan M de, Raterman B,. Vergelijking van de ecologische modellen ECOMOD en NICHE-duinen. 2004. Waterleidingbedrijf Amsterdam.

Gowing DJG, Gilbert JC, Youngs EG, Spoor G. Water regime requirements of the native flora - with particular reference to ESAs. 1997 MAFF commissioned project Silsoe College, Cranfield University. 
Gowing DJG, Lawson CS, Youngs EG, Barber KR, Rodwell JS, Prosser MV, Wallace HL, Mountford JO, Spoor G. The water regime requirements and the response to hydrological change of grassland plant communities. 2002 DEFRA-commissioned project BD1310. Final report. Institute of Water and Environment, Silsoe, Bedfordshire.

Gowing DJG, Lawson CS, Barber KR, Youngs EG. Response of grassland plant communities to altered hydrological management. 2005 DEFRA-commissioned project BD1321. Final Report. Institute of Water and Environment, Silsoe, Bedfordshire.

Grootjans AP, Adema EB, Bekker RM, Lammerts EJ. Why coastal dune slacks sustain a high biodiversity. In: Martinez ML, Psuty NP editors. Coastal Dunes: Ecology and Conservation. Ecological Studies. Berlin: Springer; 2004. p. 85-101.

Grootjans AP, Ernst WHO, Stuyfzand PJ. European dune slacks: strong interactions of biology, pedogenesis and hydrology. Trends Ecol Evolut 1998; 13: 96-100.

Grootjans AP, Hartog PS, Fresco LFM, Esselink H. Succession and fluctuation in a wet dune slack in relation to hydrological changes. J Veg Sci 1991; 2: 545-54.

Grootjans AP, Hendriksma P, Engelmoer M, Westhoff V. Vegetation dynamics in a wet dune slack I: rare species decline on the Wadden island of Schiermonnikoog in the Netherlands. Acta Bot Neerl 1988; 37: 265-78.

Grootjans AP, Sival FP, Stuyfzand PJ. Hydro-Geochemical Analysis of a Degraded Dune Slack. Vegetatio 1996; 126: 27-38.

Hill MO. TWINSPAN - a FORTRAN program for arranging multivariate data in an ordered two-way table by classification of the individuals and attributes. Ithaca, New York: Cornell University; 1979.

Hill MO, Mountford JO, Roy DB, Bunce RGH. ECOFACT 2a Technical Annex Ellenberg's indicator values for British plants. In: Bunce RGH, Smart SM, van de Poll HM, 

vegetation. Huntingdon: HMSO;1999.

597

Hill MO, Preston CD, Smith AJE. Atlas of the Bryophytes of Britain and Ireland. Colchester: Harley Books; 1991-94.

Hill MO, Roy DB, Preston CD. Appendix 11: Development of environmental indices (Ellenberg-style scores) for British bryophytes. In Atmospheric nitrogen pollution impacts on biodiversity: Phase 1 - Model development and testing (CR0289). Final report to Department of the Environment, Food and Rural Affairs, Joint Nature Conservation Committee and English Nature. (eds S. Smart, C. Evans, E. Rowe, W. Wamelink, S. Wright, W.A. Scott, D. Roy, C. Preston, M. Hill, P.Rothery, J. Bullock, I. Moy, B. Emmett \& L. Maskell). London: Defra; 2005.

Joint Nature Conservation Committee JNCC Second Report by the UK under Article 17 on the implementation of the Habitats Directive from January 2001 to December 2006. Peterborough: JNCC; 2007.

Jones MLM, Reynolds B, Brittain SA, Norris DA, Rhind PM, Jones RE. Complex hydrological controls on wet sand dune slacks: The importance of local variability. Sci Total Environ 2006; 372: 266-77.

Jones MLM, Sowerby A, Williams DL, Jones RE. Factors controlling soil development in sand dunes: evidence from a coastal dune soil chronosequence. Plant Soil 2008; 307(1-2): 219-34.

Jones MLM, Sowerby A, Rhind PM. Factors affecting vegetation establishment and development in a sand dune chronosequence at Newborough Warren, North Wales. J Coast Cons 2010; 14: 127-37. 

vegetation and soil characteristics in coastal sand dunes along a gradient of atmospheric nitrogen deposition. Plant Biol 2004; 6: 598-605.

Jones PS. Ecological and Hydrological Studies of Dune Slack Vegetation at Kenfig National Nature Reserve, Mid Glamorgan. Ph.D Thesis. University of Wales, 1993.

Jones R, Etherington JR. Comparative Studies of Plant Growth and Distribution in Relation to Waterlogging: IV. The Growth of Dune and Dune Slack Plants. J Ecol 1971; 59: 793-801.

Kalusova V, Le Duc MG, Gilbert JC, Lawson CS, Gowing DJG, Marrs RH. Determining the important environmental variables controlling plant species community composition in mesotrophic grasslands in Great Britain. App Veg Sci 2009; 12: 459-71.

Kooijman AM. Environmental problems and restoration in coastal dunes in the Netherlands. In: Martinez ML, Psuty NP editors. Coastal Dunes: Ecology and Conservation. Ecological Studies 171. pp. 243-258. Berlin: Springer; 2004. p. 243-58.

Lammerts EJ, Grootjans AP. Nutrient deficiency in dune slack pioneer vegetation: a review. J Coast Cons 1997; 3: 87-94.

Lammerts EJ, Grootjans AP. Key environmental variables determining the occurrence and life span of basiphilous dune slack vegetation. Acta Bot Neerl 1998; 47: 369-92. Ecol Eng 2001; 17: 33-47.

638 Louisse CJ, van der Meulen F. Future Coastal Defence in the Netherlands: Strategies for Protection and Sustainable Development. J Coast Research 1991; 7: 1027-41. 
643 Martinez ML, Maun MA, Psuty NP. The fragility and conservation of the world's coastal dunes: geomorphological, ecological and socio-economic perspectives. In: Martinez ML, Psuty NP editors. Coastal Dunes: Ecology and Conservation. Ecological Studies. 171, pp. 355-369. Berlin: Springer; 2004. p. 355-69.

Noest V. A hydrology-vegetation interaction model for predicting the occurrence of plant species in dune slacks. J Env Man 1994; 40: 119-28.

Olff H, Huismann J, Van Tooren BF. Species dynamics and nutrient accumulation during early primary succession in coastal sand dunes. J Ecol 1993; 81: 693-706.

Plassmann K, Brown N, Jones MLM \& Edwards-Jones G. .Can atmospheric input of nitrogen affect seed bank dynamics in habitats of conservation interest? The case of dune slacks. App Veg Sci 2008; 11: 413-20.

Plassmann K, Jones MLM, Edwards-Jones G. Effects of long-term grazing management on sand dune vegetation of high conservation interest. App Veg Sci 2010; 13: 100-12.

Provoost S, Jones MLM, Edmondson SE. Changes in landscape and vegetation of coastal dunes in northwest Europe: a review. J Coast Cons 2011; 15: 207-26.

Ranwell D. Newborough Warren, Anglesey: I. The dune system and dune slack habitat. J Ecol 1959; 47: 571-601.

Ranwell D. Newborough Warren, Anglesey: II. Plant Associes and Succession Cycles of the Sand Dune and Dune Slack Vegetation. J Ecol 1960; 48: 117-41.

662 Rhind PM, Jones PS. The Floristics and Conservation Status of Sand-Dune Communities in 663 Wales. J Coast Cons 1999; 5: 31-42.

664 Robins NS, Jones MLM. Hydroecological 'indicators of alteration' - a robust measure of change in dune slacks. Ecohydrology 2012. [online - DOI: 10.1002/eco.1264]

666 Rodwell JS. British plant communities, Volume 5: Maritime communities and vegetation of 667 open habitats. Cambridge: Cambridge University Press; 2000. 
668 Saye SE, Pye K. Implications of Sea Level Rise for Coastal Dune Habitat Conservation in Wales, UK. J Coast Cons 2007; 11: 31-52.

Schat H. A comparative ecophysiological study on the effects of waterlogging and submergence on dune slack plants: growth, survival and mineral nutrition in sand culture experiments. Oecologia 1984; 62: 279-86.

Sival FP, Grootjans AP. Dynamics of Seasonal Bicarbonate Supply in a Dune Slack: Effects on Organic Matter, Nitrogen Pool and Vegetation Succession. Vegetatio 1996; 126: 39-50.

Sival FP, Mücher HJ, Delft SPJv. Management of Basiphilous Dune Slack Communities in Relation to Carbonate Accumulation and Hydrological Conditions. J Coast Cons 1998; 4: 91-100.

Sival FP, Strijkstra-Kalk M. Atmospheric Deposition of Acidifying and Eutrophicating Substances in Dune Slacks. Water Air Soil Poll 1999; 116: 461-77.

Smith PH. Changes in the floristic composition of sand-dune slacks over a twenty year period. Watsonia 2006; 26: 41-9.

Stratford C, Ratcliffe J, Hughes AG, Roberts J, Robins NS. Complex interaction between shallow groundwater and changing woodland, surface water, grazing and other influences in partly wooded duneland in Anglesey, Wales. In: Proceedings CDXXXV Congress International Association of Hydrogeologists: Groundwater and Ecosystems. International Association of Hydrogeologists 2007; 1-10.

Studer-Ehrensberger K, Studer C, Crawford RMM. Competition at Community Boundaries: Mechanisms of Vegetation Structure in a Dune-Slack Complex. Func Ecol 1993; 7: 156-68.

691 ter Braak CJF, Smilauer P. CANOCO 4.0 Reference manual and user guide to Canoco for Windows. Ithaca, NY: Microcomputer Power; 1998. 
693 Van Dijk E, Grootjans AP. Wet dune slacks; decline and new opportunities. Hydrobiologia 694 1993; 265: 281-304.

695

Van der Laan D. Spatial and Temporal Variation in the Vegetation of Dune Slacks in Relation to the Ground Water Regime. Vegetatio 1979; 39: 43-51.

697 Von Asmuth JR, Maas K, Knotters M, Bierkens MFP, Bakker M, Olsthoorn TN, Cirkel DG,

698 Leunk I, Schaars F, \& von Asmuth DC. Software for hydrogeologic time series

699 analysis, interfacing data with physical insight. Environ Modelling and Software.

700 2012; 38: $178-190$.

701

Westhoff V, den Held AJ. Plantengemeenschappen in Nederland. Zutphen: Thieme; 1969.

Willis AJ, Folkes BF, Hope-Simpson JF, Yemm EW. Braunton Burrows: the dune system and its vegetation. Part II. J Ecol 1959b; 47: 249-88.

704

Witte J-PM, Wójcik RB, Torfs PJJF. de Haan, MWH \& Hennekens S. Bayesian classification of vegetation types. J Veg Sci 2007; 18: 605-612

Younger PL, Teutsch G, Custodio E, Elliot T, Manzano M, Sauter M. Assessments of the sensitivity to climate change of flow and natural water quality in four major carbonate aquifers of Europe. In: Hiscock KM, Rivett MO, Davison RM, editors. Response of Aquifers to Future Climate Change. p. 303-23.

710 Yusoff I, Hiscock KM, Conway D. Simulation of the impacts of climate change on groundwater resources in eastern England. In: Hiscock KM, Rivett MO, Davison RM, editors. Response of Aquifers to Future Climate Change. p. 325-44. 
716 Figure 1. Typical hydrographs showing monthly water levels at Newborough Warren over a

717 four year period (2006-2009) for four dune slack communities and one dry grassland

718 community (SD8) for comparison. y axis shows metres above ground level, zero represents

719 ground surface.

720

721 Figure 2. PCA scores of the 245 quadrats, coded by vegetation community. The first three axes (Eigenvalues $0.13,0.11,0.06$ ) explain $29.6 \%$ of the variance. See table 4 for full list of environmental variables.

Figure 3. CCA ordination analysis (a) distribution of environmental variables along first two axes, (b) distribution of quadrats grouped by NVC -core and transitional vegetation-, (c) distribution of quadrats representing core vegetation only, and distinguishing between SD14 subcommunities. See table 4 for a complete list of variables.

Figure 4. Average ion concentrations in soil, by vegetation community (core plus transitional vegetation) -bars represent SE-. a) anions; b) cations. Calcium is downscaled 10 times to be visualised with the other cations (e.g.: $1=10 \mathrm{mg} / 100 \mathrm{~g}$ dry soil).

734 Figure 5. Plot of hydrological niche occupied by three dune slack vegetation communities and dry dune grassland showing mean annual maximum (i.e. winter) and minimum (i.e. summer) water levels (metres above ground level, zero = ground surface), based on four-year hydrological regime (2006-2009). Thick inner lines indicate bounds of 67\%ile of their

738 distribution, thinner outer lines represent bounds for 90\%ile. Dashed lines denote mean 
annual maximum water levels for dry dune grassland based on quadrats surveyed in this

740 study.

741

742 Figure 6. Frequency distribution curves of median water level for different slack types (data

743 from this study, rescaled on $2^{\text {nd }} y$ axis to $\max =1$ ), plotted against predicted changes in April

744 water level (metres above ground level, $1^{\text {st }}$ y axis) of a currently wet dune slack (SD15) at

745 Ainsdale in north west England (after Clarke \& Sanitwong Na Ayutthaya, 2010). Predicted

746 April water levels show central estimate (thin black line), 75\% confidence interval (dark grey

747 zone) and 90\% confidence interval (light grey zone).

748

749

750

Table 1: Locations and details of survey sites.

\begin{tabular}{llccccc}
\hline \hline Site & $\begin{array}{l}\text { Latitude, } \\
\text { Longitude }\end{array}$ & $\begin{array}{l}\text { Rainfall } \\
1971-2000 \\
\text { 1.t.a. }(\mathrm{mm})\end{array}$ & $\begin{array}{l}\text { Dune area } \\
\text { (ha) }\end{array}$ & Piezometers & $\begin{array}{l}\text { Slacks } \\
\text { surveyed }\end{array}$ & Quadrats \\
\hline \hline $\begin{array}{l}\text { Newborough } \\
\text { Warren }\end{array}$ & $\begin{array}{l}53^{\circ} 08^{\prime} \mathrm{N}, \\
4^{\circ} 21^{\prime} \mathrm{W}\end{array}$ & 830 & 529 & 49 & 46 & 212 \\
$\begin{array}{l}53^{\circ} 11^{\prime} \mathrm{N}, \\
4^{\circ} 27^{\prime} \mathrm{W}\end{array}$ & 830 & 248 & 2 & 2 & 12 \\
$\begin{array}{l}53^{\circ} 35^{\prime} \mathrm{N}, \\
3^{\circ} 4^{\prime} \mathrm{W}\end{array}$ & 870 & 508 & 3 & 3 & 9 \\
$\begin{array}{l}51^{\circ} 38^{\prime} \mathrm{N}, \\
4^{\circ} 14^{\prime} \mathrm{W}\end{array}$ & 1110 & 142 & 4 & 4 & 12 \\
Bhinsdale & & & & & 2 \\
\hline \hline
\end{tabular}

751 
Table 2: Summary of National Vegetation Classification communities and subcommunities identified in this study (adapted from Rodwell, 2000). Affinities with European vegetation associations in brackets.

\begin{tabular}{|c|c|c|c|}
\hline \multicolumn{3}{|c|}{ NVC code Name } & \multirow{2}{*}{$\begin{array}{l}\text { Description } \\
\\
\text { Early successional stage, rich in } \\
\text { bryophytes and liverworts. Usually with } \\
\text { bare sand. Fairly drought tolerant. }\end{array}$} \\
\hline SD13 & $\begin{array}{l}\text { Sagina nodosa-Bryum pseudotriquetrum } \\
\text { community } \\
\text { (Saginion maritimae Westhoff, van Leeuwen } \\
\text { \& Adriani 1962, Samolo-Littorelletum } \\
\text { Westhoff 1943) }\end{array}$ & & \\
\hline SD14 & $\begin{array}{l}\text { Salix repens-Campylium stellatum } \\
\text { Community } \\
\text { (Junco baltici-Shoenetum nigricantis } \\
\text { Westhoff 1946, Pyrolo-Salicetum Meltzer } \\
\text { 1941) }\end{array}$ & \multirow{5}{*}{ 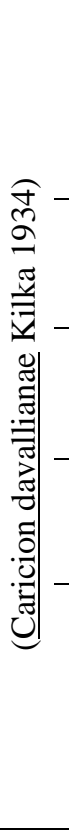 } & $\begin{array}{l}\text { Frequently species rich and associated with } \\
\text { persistently humid soils and base-rich } \\
\text { groundwater. Several rare species occur in } \\
\text { this vegetation. }\end{array}$ \\
\hline SD14b & $\begin{array}{l}\text { Rubus caesius-Galium palustre } \\
\text { subcommunity }\end{array}$ & & $\begin{array}{l}\text { Some of its constant species (Ranunculus } \\
\text { flammula, Carex nigra) can indicate } \\
\text { tolerance to very wet periods. }\end{array}$ \\
\hline $\mathrm{SD} 14 \mathrm{c}$ & $\begin{array}{l}\text { Bryum pseudotriquetrum-Aneura pinguis } \\
\text { subcommunity }\end{array}$ & & $\begin{array}{l}\text { Young successional stage, mosses have } \\
\text { sparse cover, heliophilous and pioneer } \\
\text { species can be present. }\end{array}$ \\
\hline SD14d & $\begin{array}{l}\text { Festuca rubra } \\
\text { subcommunity }\end{array}$ & & $\begin{array}{l}\text { Characteristic of drier substrates, it can be } \\
\text { an intermediate stage towards grass } \\
\text { encroachment. }\end{array}$ \\
\hline SD15b & $\begin{array}{l}\text { Salix repens-Calliergon cuspidatum } \\
\text { community } \\
\text { Equisetum variegatum } \\
\text { subcommunity } \\
\text { (Equiseto variegati-Salicetum repentis } \\
\text { Westhoff \& Schaminèe } 1995 \text { ) } \\
\end{array}$ & & $\begin{array}{l}\text { Late successional stage, generally species } \\
\text { poor. Less dependent on base-richness of } \\
\text { water, but strongly related with flooding. }\end{array}$ \\
\hline SD16 & $\begin{array}{l}\text { Salix repens-Holcus lanatus } \\
\text { Community } \\
\text { (Salicion repentis arenariae Tüxen 1952) }\end{array}$ & & $\begin{array}{l}\text { Late successional stage in dry slacks. } \\
\text { Dominated by fescue and grasses, forbs are } \\
\text { still indicative of calcicolous substrate }\end{array}$ \\
\hline SD17 & $\begin{array}{l}\text { Potentilla anserina-Carex nigra } \\
\text { Community } \\
\text { (Elymo-Rumicion crispi Nordhagen 1940) }\end{array}$ & & $\begin{array}{l}\text { Species composition reflects damp habitat, } \\
\text { recalling fen meadows. Forbs-rich, with a } \\
\text { sparse shrub cover. }\end{array}$ \\
\hline SD8b & $\begin{array}{l}\text { Festuca rubra-Galium verum } \\
\text { Community } \\
\text { Luzula campestris } \\
\text { subcommunity } \\
\text { (Galio-Koelerion, Westhoff and den Held } \\
\text { 1969). }\end{array}$ & & $\begin{array}{l}\text { Dune grassland rich in dicotyledons } \\
\text { characteristic of fixed sands. This } \\
\text { vegetation has some affinities with a } \\
\text { calcicolous sward. }\end{array}$ \\
\hline
\end{tabular}


Table 3. Environmental variables used in vegetation analysis, showing percentage of total species variation explained within $\mathrm{CCA}$ and significance, when tested singly or in combination. *: significant at 0.05 level; **: significant at 0.01 level; ***: significant at 0.001 level.

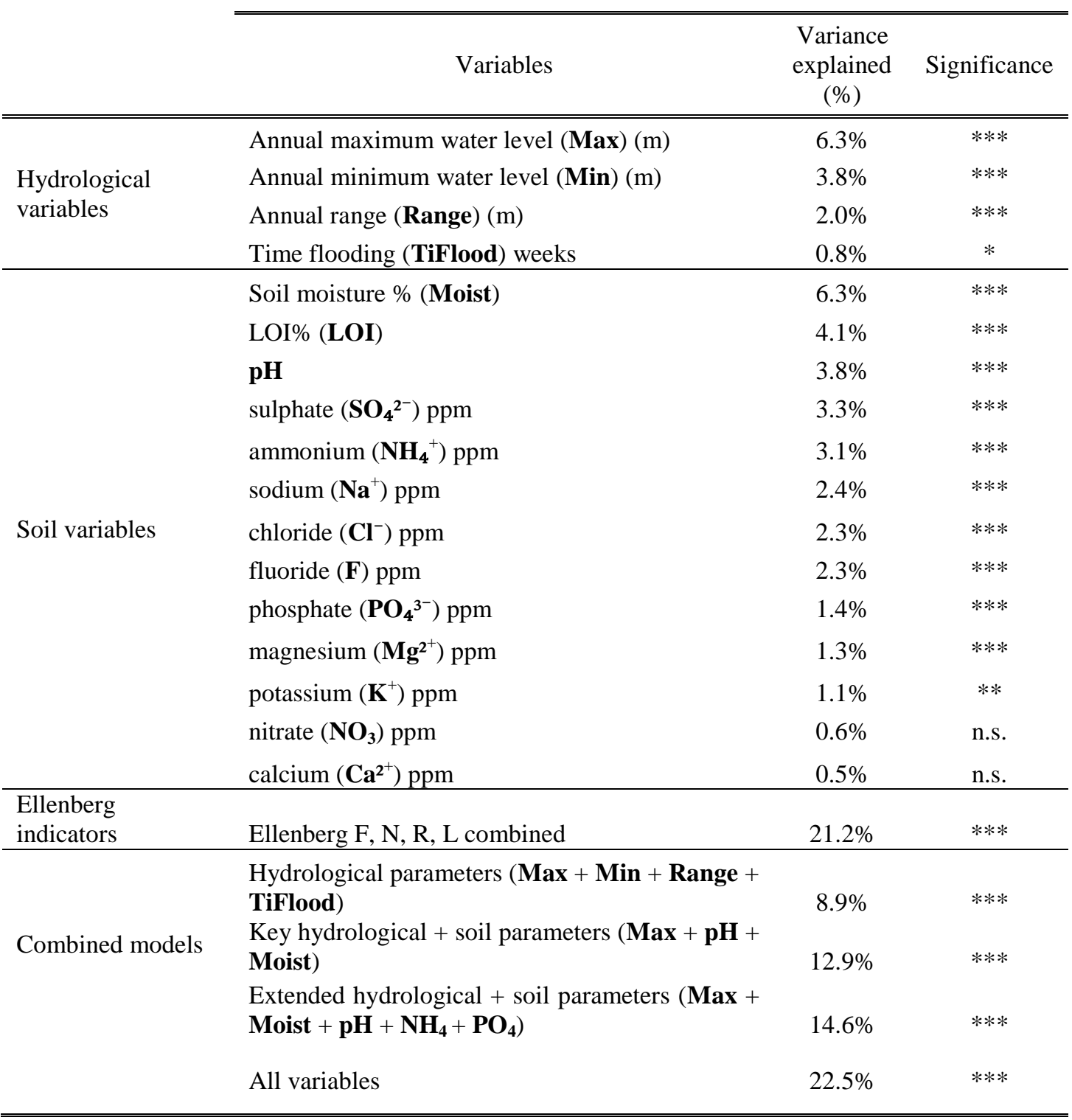




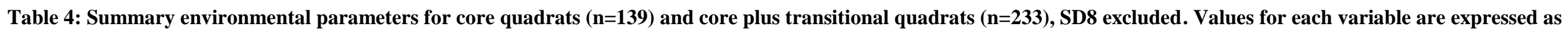

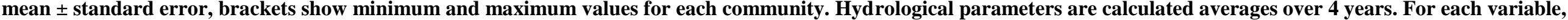

lower case letters denote significant differences between community types using core quadrats only, upper case letters for tests using core plus transitional quadrats.

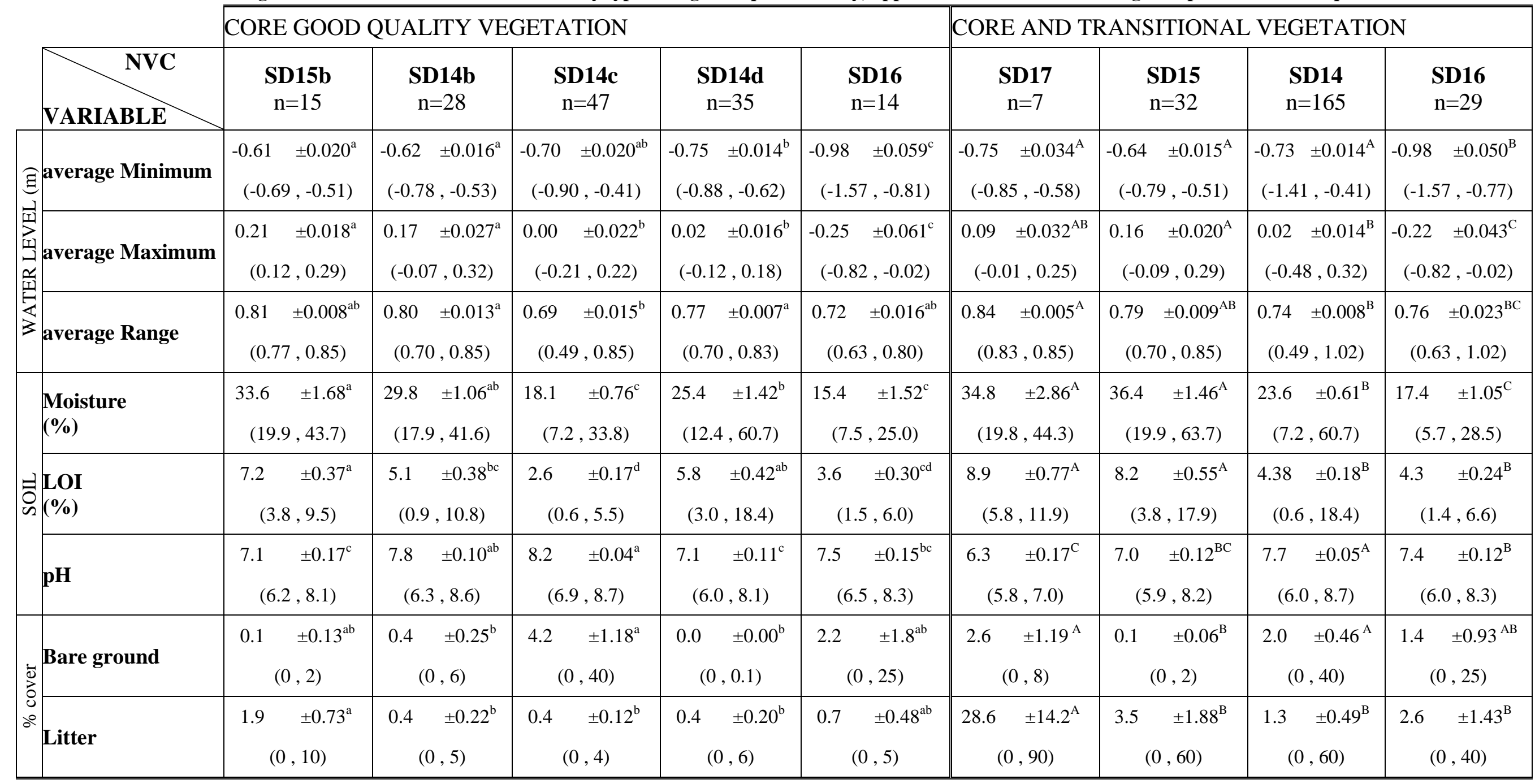


Figure 1.

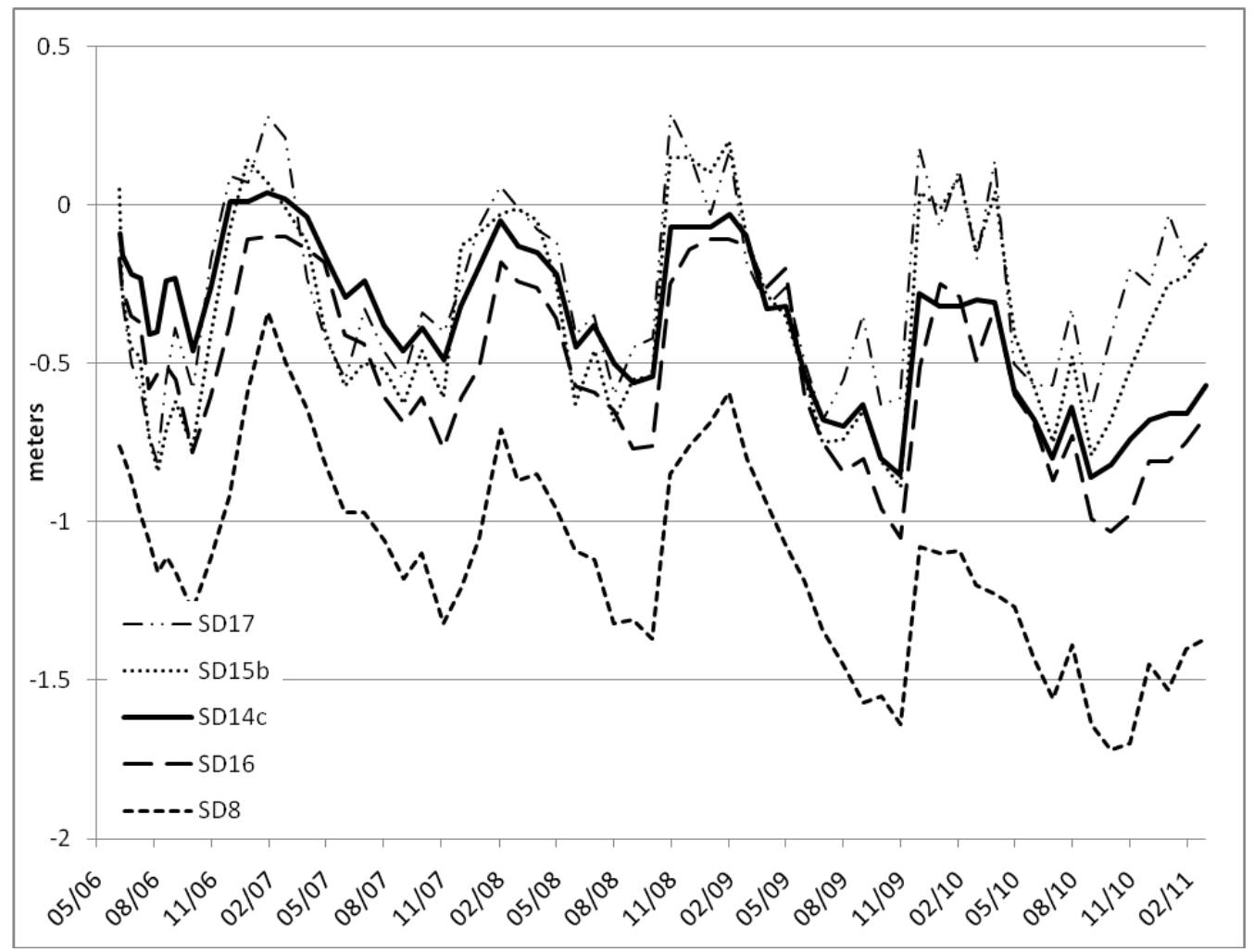

6
7
8
9
10 
11

13

14

15

16

Figure 2.

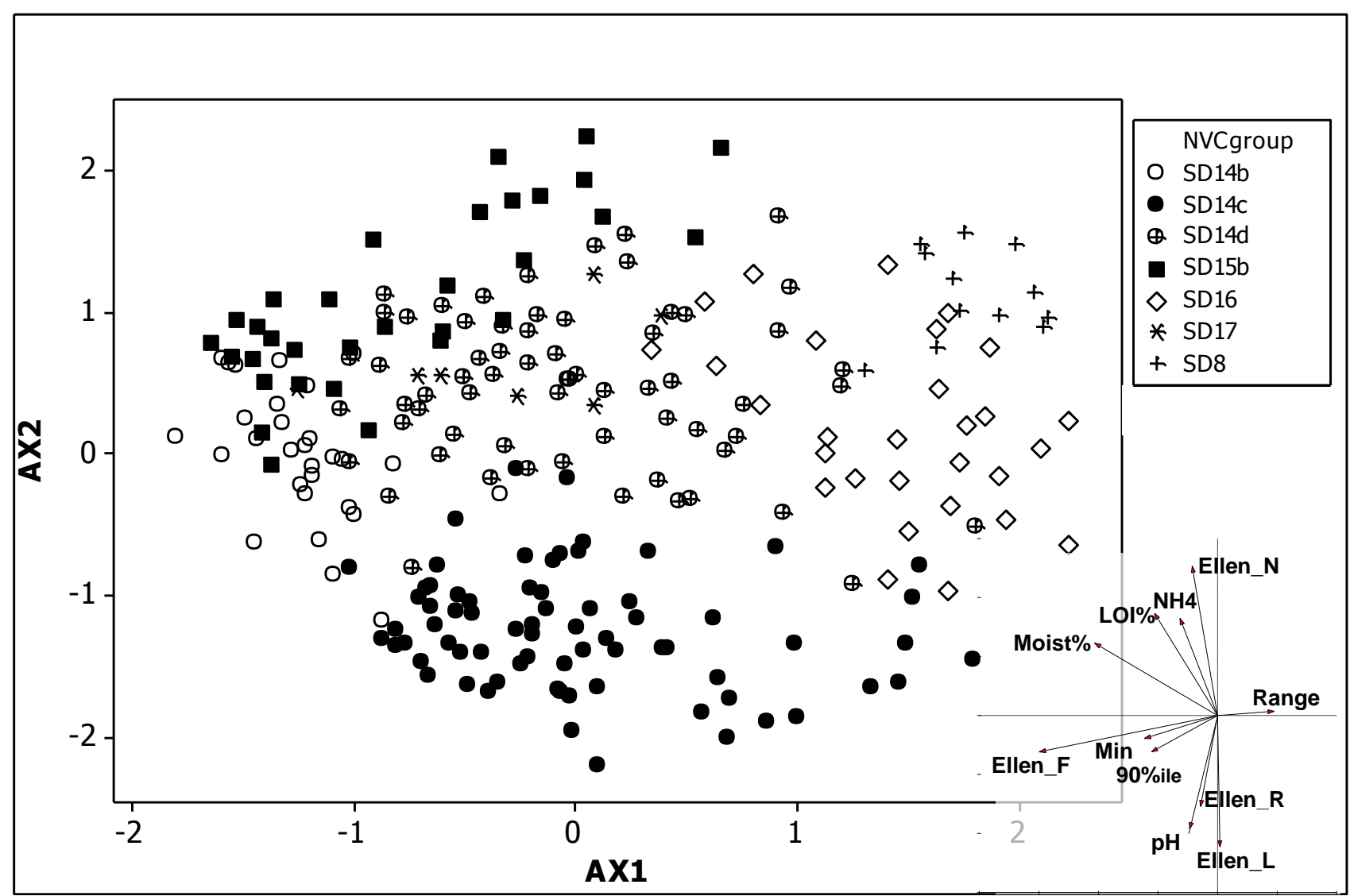


51

52

53

54

55

56

57

58

59

60

61

62

63

Figure 3.
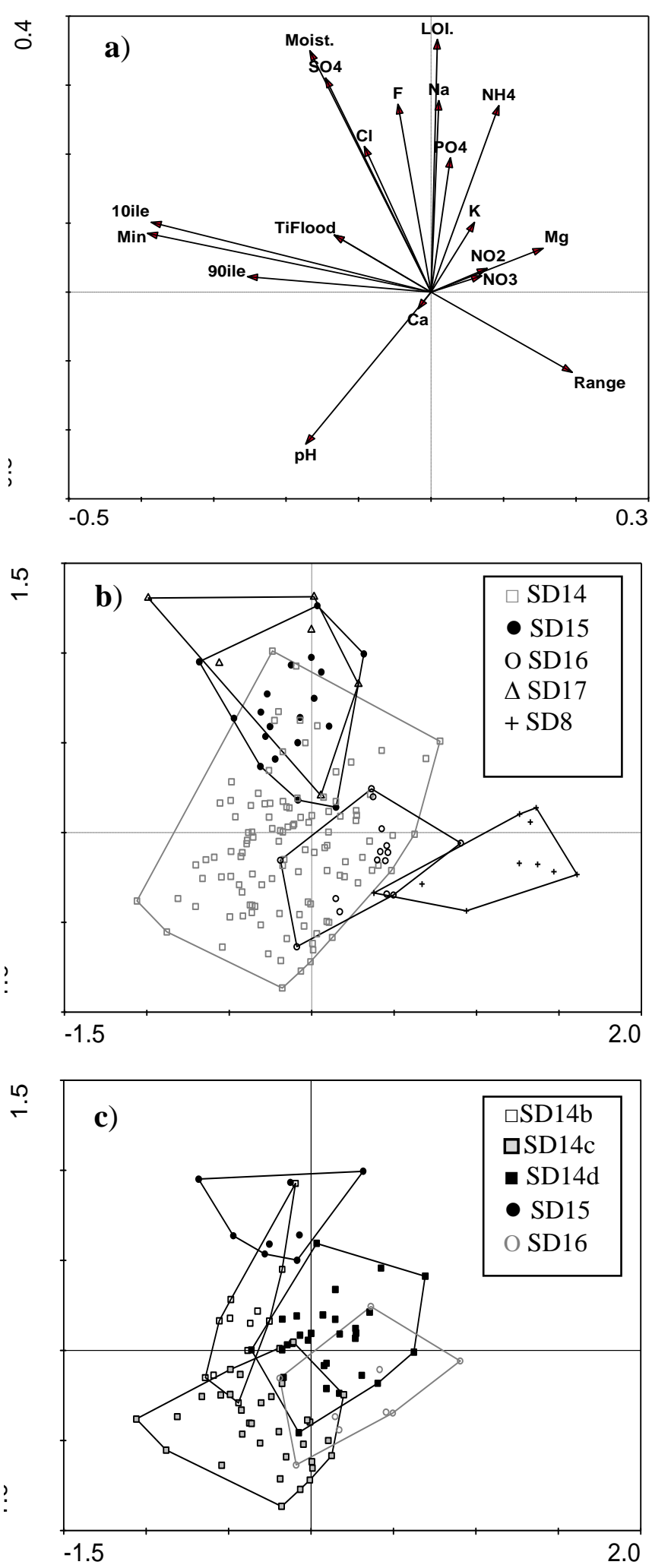
Figure 4.
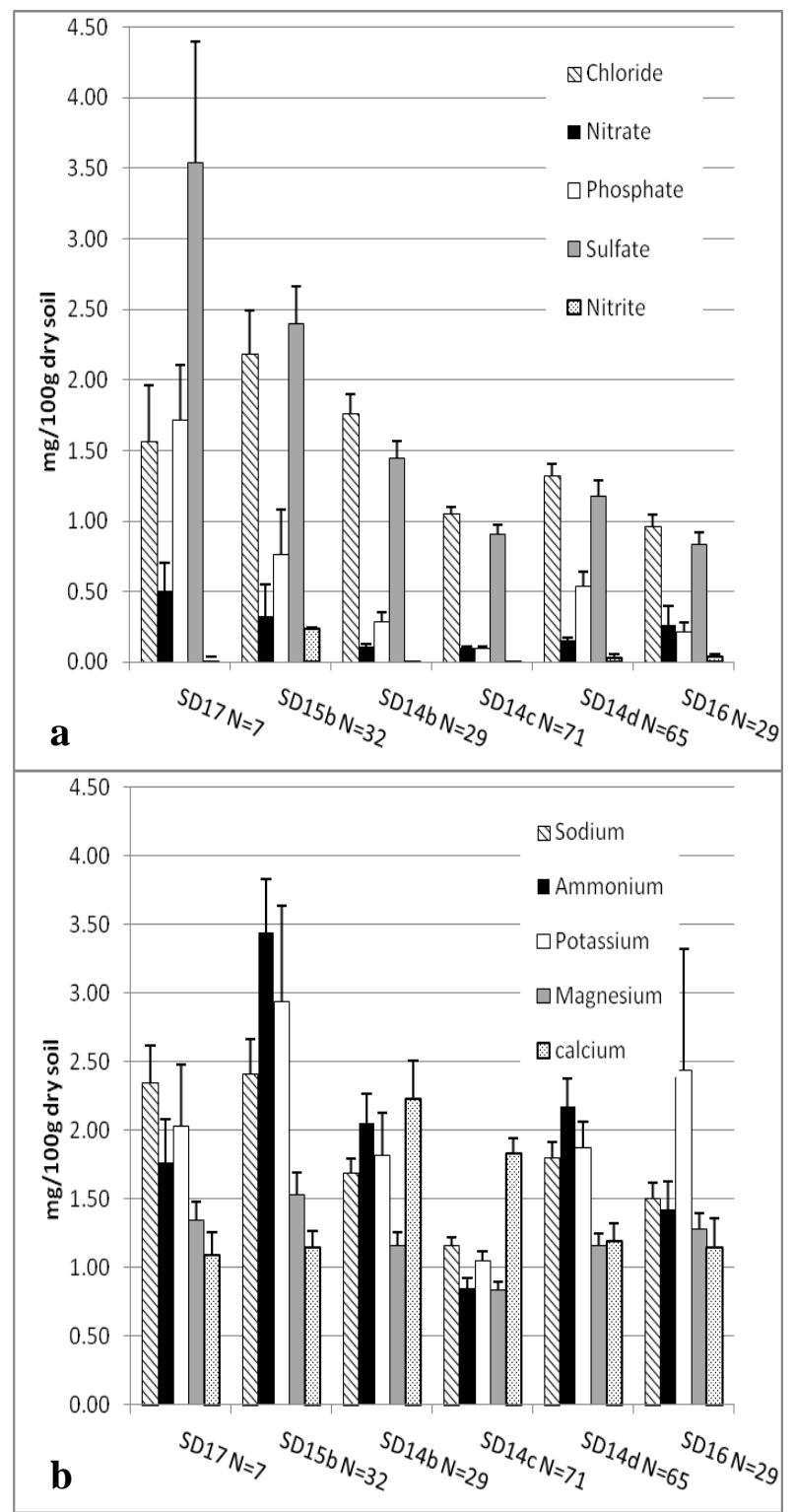
109

110

111

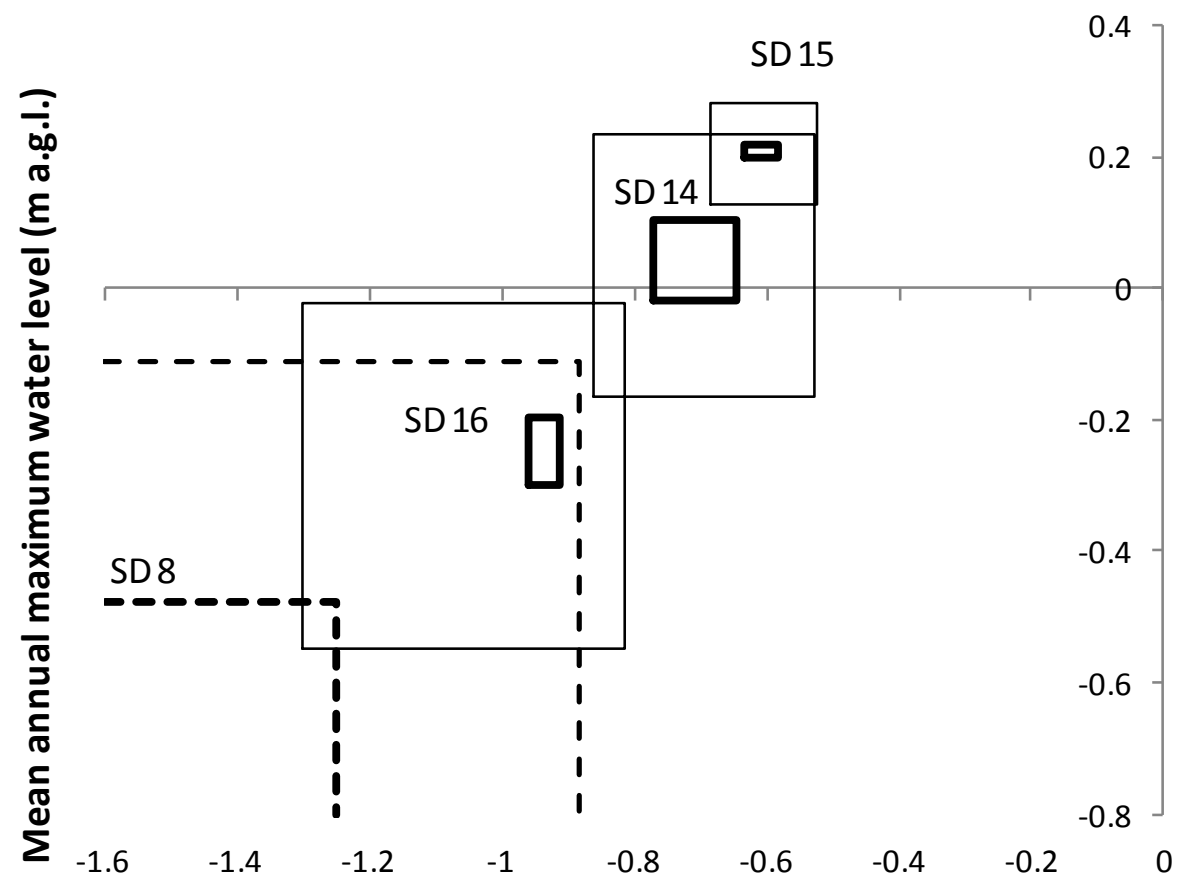

112

114

115

116

117

118

119

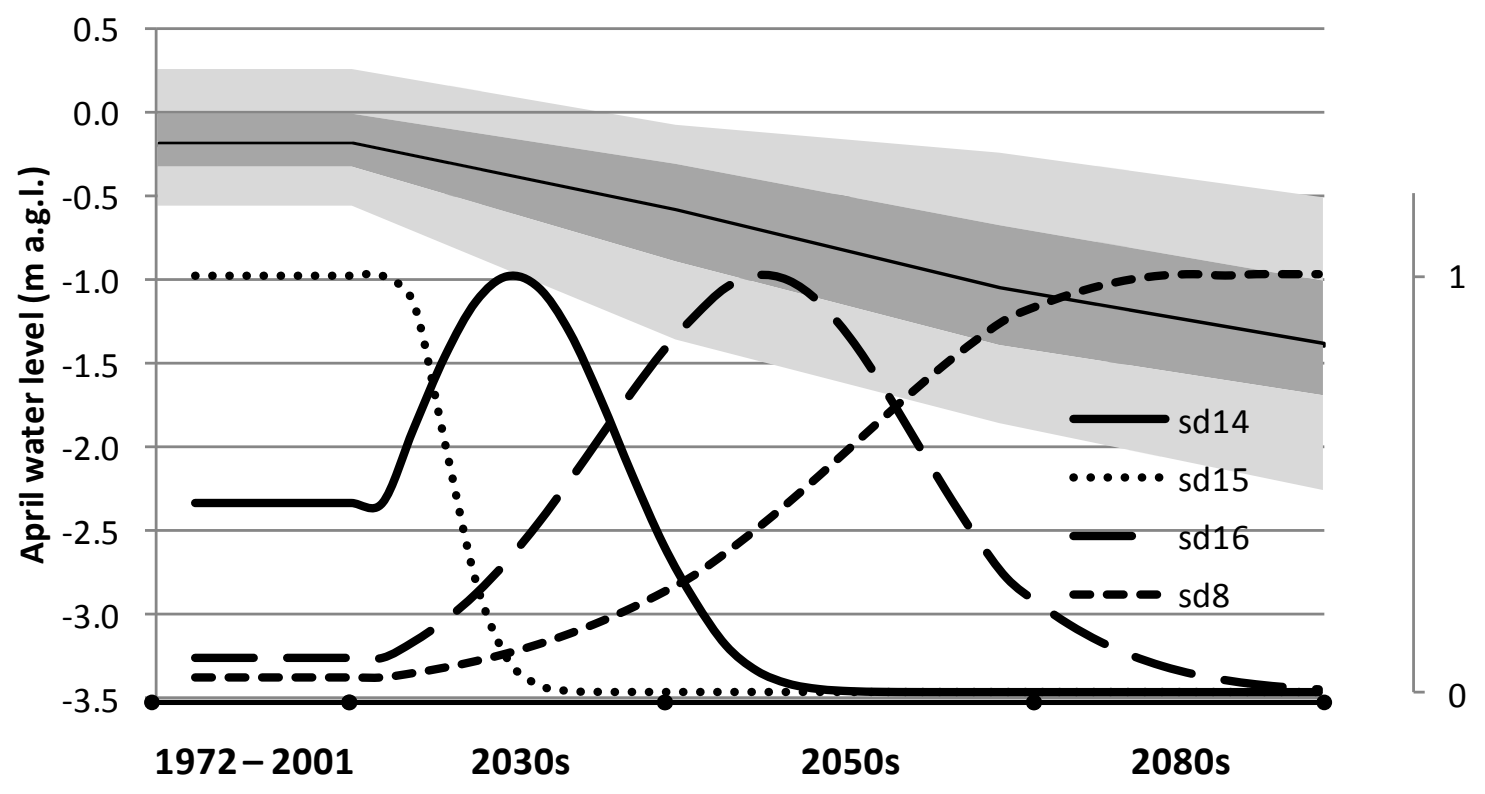

Figure 6

Mean annual minimum water level (m a.g.I.) 